\title{
これすぱんですす
}

\section{オペアンプと集積化したpoly-Si ホール素子の磁場応答特性}

Magnetic-Field Response Characteristic of poly-Si Hall Device integrated with Operational Amplifier

木村睦 ${ }^{\dagger}$, 吉川朗登 ${ }^{\dagger}$, 松本貴明 ${ }^{\dagger}$, 松田時宜 ${ }^{\dagger}$, 小澤徳郎 ${ }^{\dagger}$, 青木幸司 ${ }^{\dagger}$, 郭志徹 ${ }^{\dagger}$ Mutsumi Kimura $^{\dagger}$, Akito Yoshikawa ${ }^{\dagger}$, Takaaki Matsumoto ${ }^{\dagger}$, Tokiyoshi Matsuda ${ }^{\dagger}$. Tokuro Ozawa ${ }^{\dagger \dagger}$, Koji Aoki ${ }^{\dagger \dagger}$ and Chih-Che Kuo ${ }^{\dagger \dagger}$

あらまし 磁場センサへ応用することを想定して，オペアンプと集積化した poly-Si ホール素子の磁場応答特性を評 価した。ホール素子の磁場感度 $11.8 \mathrm{mV} / \mathrm{T}$ は，オペアンプで $1.14 \mathrm{~V} / \mathrm{T}$ まで向上した. Poly-Si TFTのアナログ回路へ の適用の好例である。

キーワード：オペアンプ, 集積化, poly-Siホール素子, 磁場応答特性, 磁場センサ, 感度, アナログ回路

\section{1.まえがき}

薄膜トランジスタ $(\mathrm{TFT})^{1)}$ は, 液晶ディスプレイ $(\mathrm{LCD})^{2)}$ や有機ELディスプレイ (OLED) ${ }^{3)}$ などのフラットパネル ディスプレイ $(\mathrm{FPD})^{4)}$ の駆動素子として, 広く用いられて いる. 特に, poly-Si TFT ${ }^{5)}$ は, 高性能でn型と $\mathrm{p}$ 型トラン ジスタによる相補回路が作製できるため, FPDの内蔵駆動 回路をはじめ各種のディジタル回路を集積化したシステム オンパネル (SOP) の実現が期待されている。いっぽう, FPDから派生して, TFTによるセンシングデバイス ${ }^{6)}$ の研 究がさかんである.FPD とさまざまのセンシングデバイス を同一パネルに作り込めば，マルチインタラクティブデバ イスが得られる。もちろんセンシングデバイス単体であっ ても, リアルタイムエリアセンサなどの新規アプリケー ションの可能性が考えられる。 センシングデバイスでは, アナログ回路を中心とした増幅回路があれば，センシング 感度の向上が見込まれる.

筆者らは，磁場センサへ応用することを想定して，オペア ンプと集積化した poly-Si ホール素子の磁場応答特性を評価 した. Poly-Si ホール素子の磁場感度を, オペアンプの増幅機 能で向上させることが可能となる. これまで, poly-Siホール 素子による磁場センサの報告はあるものの ${ }^{7)}$, オペアンプと 集積化されたことはなく，またそのほかのセンシングデバイ スに対しても, オペアンプと集積化された例はほとんどない. 今回は磁場センサへの適用であるが, より一般的にさまざま なセンシングデバイスに対して, poly-Si TFTがアナログ回 路としても応用できることを示している.

\footnotetext{
2015 年 3 月 2 日受付，2015年 5 月 9 日再受付，2015年 5 月 20 日採録

$\dagger$ 龍谷大学 理工学部 電子情報学科

（～520-2194 大津市瀬田大江町横谷 1-5, TEL 077-543-7407)

†株式会社日本エーユー・オプトロニクス研究開発部

（† 105-0014 港区芝3-24-21三和ビル5階，TEL 03-6414-7388）
}

\section{Poly-Siホール素子とオペアンプ}

Poly-Siホール素子を図1(a)に，オペアンプを図1(b)に 示す.これらの poly-Si ホール素子とオペアンプを, 同一の 通常の低温poly-Si プロセスで作製する。まず，ガラス基板 に, $\mathrm{Si}_{2} \mathrm{H}_{6}$ の減圧化学気相堆積 (LPCVD) でアモルファス $\mathrm{Si}$ を成膜し, $\mathrm{XeCl}$ のエキシマレーザで結晶化して poly-Si と し，パターニングしてチャネル領域を作製する。 そして， テトラエトキシシラン (TEOS) のプラズマ援用化学気相堆 積 $(\mathrm{PECVD})$ で $\mathrm{SiO}_{2}$ を成膜してゲート絶縁膜を作製する. 次に, Pイオンをイオンインプランテーションし, 低濃度 のチャネルドーピングを行う.そして，オペアンプのTFT では，スパッタで金属膜を製膜し，パターニングしてゲー 卜電極を作製する。次に, poly-Siホール素子では, レジス トのみをインプラマスクとしてPイオンを，オペアンプの TFTでは，ゲート電極とレジストをインプラマスクとして PイオンとBイオンをイオンインプランテーションし, 熱 活性化して高濃度のソースドレインドーパント領域を作製 する。そして，さらにTEOSのPECVDで $\mathrm{SiO}_{2}$ を成膜して 相間絶縁膜を製膜してコンタクトホールを開口する。次に, ふたたびスパッタで金属膜を製膜し，パターニングして ソースドレイン電極を作製する。最後に，やはりTEOSの PECVDで $\mathrm{SiO}_{2}$ を成膜して保護膜を作製する.

Poly-Si膜に垂直に磁場を印加すると, poly-Siホール素子 のホール電圧の磁場感度 ${ }^{8)}$ は, 次式であらわされる.

$$
\partial \mathrm{V}_{\mathrm{H}} / \partial \mathrm{B}=\mu(\mathrm{W} / \mathrm{L}) \mathrm{V}
$$

ここで, W/L=1000/4000 $\mu \mathrm{m}$ である。通常のTFTの駆動 電圧は $\mathrm{V}=10 \mathrm{~V}$ 程度で, せいぜい $\mu=100 \mathrm{~cm}^{2} / \mathrm{Vs}$ 程度であ るので, $\partial \mathrm{V}_{\mathrm{H}} / \partial \mathrm{B}=25 \mathrm{mV} / \mathrm{T}$ 程度となり, 非常に小さい. そこで，オペアンプの増幅機能を利用する.

オペアンプの回路を図 1 (c) に, それを構成するトランジ 


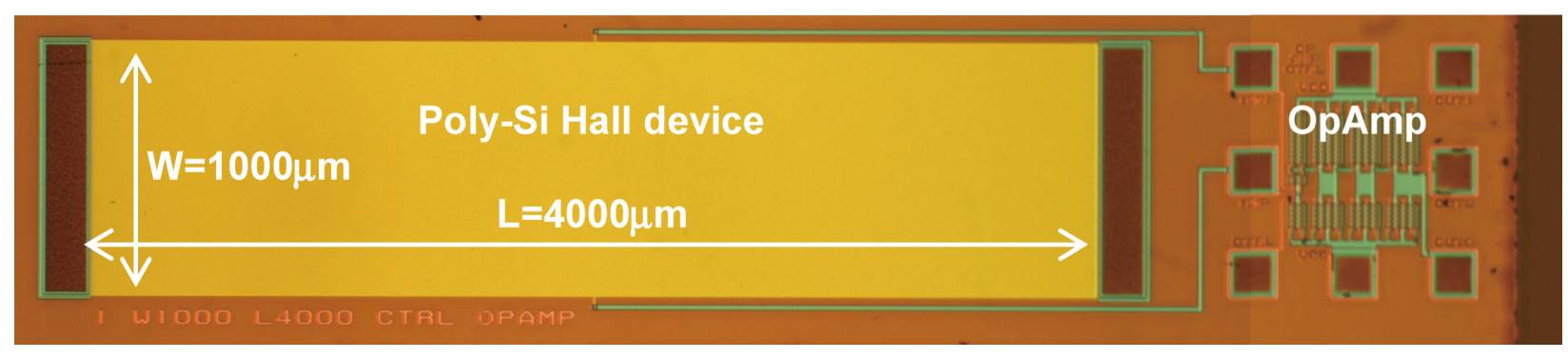

(a)Poly-Siホール素子

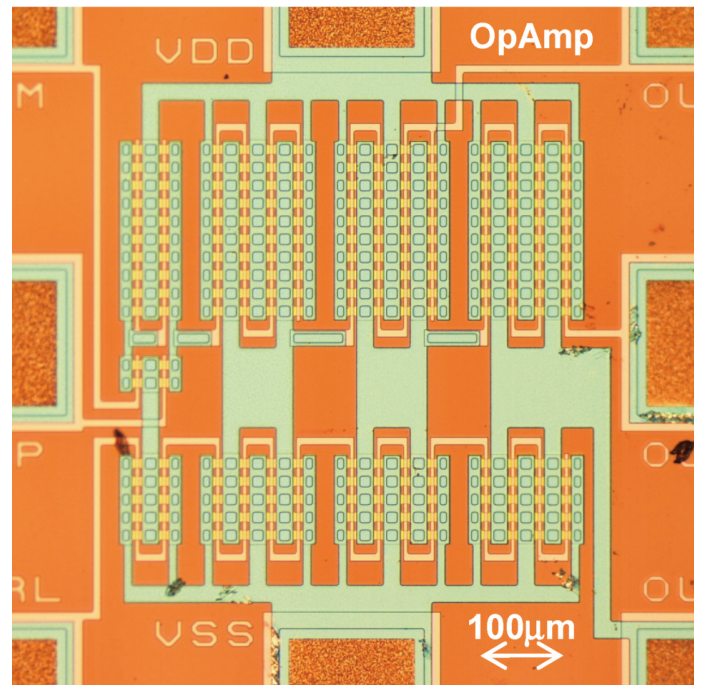

(b) オペアンプ

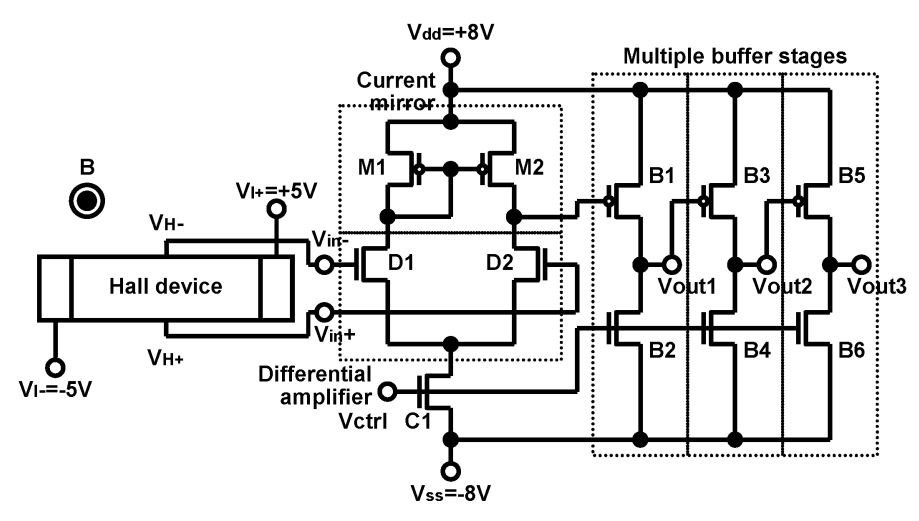

(c) オペアンプの回路

\begin{tabular}{|c|c|c|c|c|}
\hline & Type & $\begin{array}{c}\text { W } \\
(\mu \mathrm{m})\end{array}$ & $\begin{array}{c}\mathrm{L} \\
(\mu \mathrm{m})\end{array}$ & $\begin{array}{l}\text { LDD } \\
(\mu \mathrm{m})\end{array}$ \\
\hline M1 $\cdot M 2$ & $p$ & 100 & \multirow{5}{*}{4} & \multirow{5}{*}{ 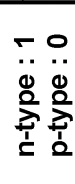 } \\
\hline $\mathrm{D} 1 \cdot \mathrm{D} 2$ & $n$ & 20 & & \\
\hline C1 & $n$ & 100 & & \\
\hline B1 $\cdot$ B3 $\cdot$ B5 & $p$ & 400 & & \\
\hline $\mathrm{B} 2 \cdot \mathrm{B} 4 \cdot \mathrm{B} 6$ & $\mathrm{n}$ & 200 & & \\
\hline
\end{tabular}

(d)トランジスタの型とサイズ

図1 Poly-Siホール素子とオペアンブ

スタの型とサイズを図 1 (d) に示す.Type は電界効果型ト ランジスタとしての導電形で, $\mathrm{n}$ 型または $\mathrm{p}$ 型である. $\mathrm{W}$ はゲート幅, Lはゲート長, LDD は低濃度ドープドレイン 長であり, $\mathrm{n}$ 型トランジスタでは $\mathrm{LDD}=1 \mu \mathrm{m}, \mathrm{p}$ 型トランジ スタでは $\mathrm{LDD}=0 \mu \mathrm{m}$ のセルフアラインドレイン構造をと る.オペアンプの回路は標準的な構成であるが, poly-Si TFTの特性を考慮し, 動作を最適化するための制御電圧 $\mathrm{V}_{\mathrm{ctrl}}$ を与えることができるようになっている. 駆動電圧は $\mathrm{V}_{\mathrm{dd}}=+8 \mathrm{~V}$ と $\mathrm{V}_{\mathrm{ss}}=-8 \mathrm{~V}$ を印加する. オペアンプの入出力 特性を図 2 に示す. 差動入力 $V_{\text {in }}=V_{\text {in }+}-V_{\text {in }}$ と最終段出力 $\mathrm{V}_{\text {out }}=\mathrm{V}_{\text {out3 }}$ の関係をみると, 制御電圧 $\mathrm{V}_{\text {ctrl }}=-8 \sim-4 \mathrm{~V}$ 程 度でかなり急峻な特性, 具体的には増幅率 $\alpha>100$ 程度が得 られている。そこで, poly-Siホール素子のホール電圧を $\mathrm{V}_{\text {in }}$ に入力し, $\mathrm{V}_{\text {out }}$ を測定する.

\section{3. 磁場感度}

オペアンプと集積化した poly-Si ホール素子を, 電磁石に

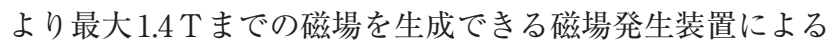
一様な磁場のなかに置き, $\mathrm{B}$ を変化させながら $\mathrm{V}_{\mathrm{H}}$ と $\mathrm{V}_{\text {out }}$ を 測定した。 $\mathrm{B}$ と $\mathrm{V}_{\mathrm{H}}$ と $\mathrm{V}_{\text {out }}$ の関係を図3に示す.Poly-Siホー ル素子の電流供給端子に, $\mathrm{V}_{\mathrm{I}+}=+5 \mathrm{~V}$ と $\mathrm{V}_{\mathrm{I}-}=-5 \mathrm{~V}$ を印加

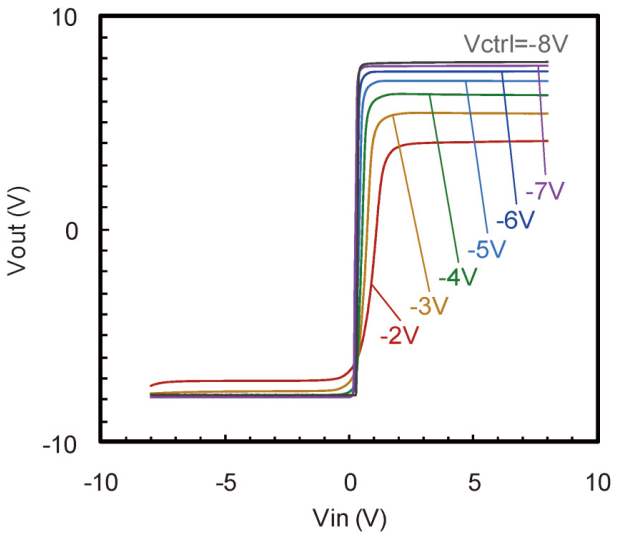

図2 オペアンプの入出力特性

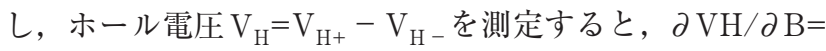
$11.8 \mathrm{mV} / \mathrm{T}$ となるので, poly-Si膜の $\mu=47.2 \mathrm{~cm}^{2} / \mathrm{Vs}$ と計算さ れる.なお，このときの poly-Si ホール素子を流れる電流は $128 \mu \mathrm{A}$ であり, 抵抗值は $78.1 \mathrm{k} \Omega$ である. また, $\mathrm{B}=0$ におけ る $\mathrm{V}_{\mathrm{H}}$ は, 筆者らがホール電圧のオフセット電圧と呼んでい るもので, poly-Si膜中のキャリヤのジグザグ経路に起因す るものである ${ }^{9)}$. いっぽう, オペアンプでは, $\partial \mathrm{V}_{\text {out }} / \partial \mathrm{B}=$ $1.14 \mathrm{~V} / \mathrm{T}$ となるので，オペアンプの増幅率は $\alpha=96.9$ と計算 


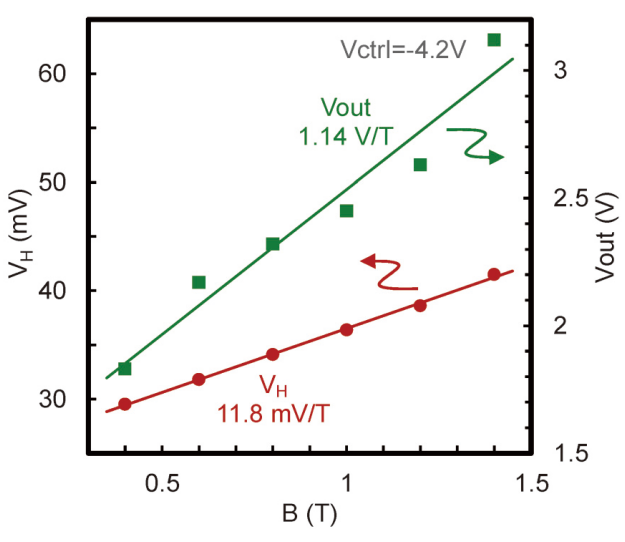

図3 BとVHとVoutの関係

される．直線からのズレはオペアンプの増幅ノイズによる ものである.ランダムノイズであるため，オペアンプの内 部ノイズによるものと考えられる. 特にpoly-Si TFTでは チャネル内トラップ準位でのキャリヤの捕獲と放出による 低周波ノイズがあることが報告されており ${ }^{10)}$ ，今後のさら なるセンシング感度の向上のためには何らかの対策が必要 となる可能性がある.なお，ここでは， $\mathrm{V}_{\mathrm{ctrl}}=-4.2 \mathrm{~V}$ とし ているが, $\mathrm{V}_{\mathrm{ctrl}}$ で $\alpha$ だけでなくオペアンプの入力オフセッ 卜電圧も変わるため, 今回は $\mathrm{V}_{\mathrm{H}}$ がプラスのオフセット電 圧を持っていたので，オペアンプの入出力特性の動作点を もっとも急峻なところに持っていくためには, この $\mathrm{V}_{\mathrm{ctrl}}$ に する必要があった。このことは, poly-Siホール素子のみな らずオペアンプにおいても，それぞれの磁場センサに対し て，動作条件のキャリブレーションが必要であることを示 唆している.

\section{4.むすび}

磁場センサへ応用することを想定して，オペアンプと集 積化したpoly-Si ホール素子の磁場応答特性を評価した. ホール素子の磁場感度 $11.8 \mathrm{mV} / \mathrm{T}$ はオペアンプで $1.14 \mathrm{~V} / \mathrm{T}$ まで向上した. Poly-Si TFTのアナログ回路への適用の好 例である，今回は磁場センサに集積化したが，そのほかの センシングデバイスはじめあらゆるアプリケーションに適 用できるはずである，ただし，入出力の線形性については 不充分なところがあり, 今後の検討が不可欠である.

謝辞 本研究の一部は, 日本エーユー・オプトロニクス との受託研究, 龍谷大学科学技術共同研究センター研究プ ロジェクト, 龍谷大学革新的材料・プロセス研究センター の支援によるものであり，感謝する.

\section{〔文 献〕}

1）薄膜材料デバイス研究会：“薄膜トランジスタ”, コロナ社, 東京 (2008)

2) 山崎照彦, 川上英昭, 堀浩雄, SEMIカラーTFT液晶ディスプレイ改 訂版編集委員会：“カラーTFT 液晶ディスプレイ (改訂版)”, 共立 出版, 東京 (2005)

3）時任静士, 安達千波矢, 村田英幸：“有機ELディスプレイ”, オーム 社, 東京 (2004)

4）内田龍男, 内池平樹：“フラットパネルディスプレイ大事典”, 工業
調査会，東京（2001）

5）浦岡行治：“低温ポリシリコン薄膜トランジスタの開発-システムオ ンパネルをめざしてエレクトロニクス材料・技術シリーズ”，シーエ ムシー出版, 東京 (2007)

6) M. Kimura, T. Matsuda, S. Noguchi, T. Sakamoto, T. Ozawa, K. Aoki and C.-C. Kuo: "Sensor Application using Thin-Film Devices derived from Display Technologies - Flatpanel Imager, Artificial Retina, Temperature Sensor, etc -", IDW '14, pp.1549-1552 (Dec. 2014)

7) F. Le Bihan, E. Carvou, B. Fortin, R. Rogel, A.C. Salaün and O. Bonnaud: "Realization of Polycrystalline Silicon Magnetic Sensors", Sensors and Actuators A: Physical, 88, 2, pp.133-138 (Feb. 2001)

8) A. Yoshikawa, D. Tadokoro, Y. Yamaguchi, T. Matsuda, M. Kimura, T. Ozawa, K. Aoki and C.-C. Kuo: "Magnetic Field Sensitivity of PolySi Hall Device improved by High Voltage Application", IMFEDK 2014, pp.86-87 (June 2014)

9) Y. Yamaguchi, H. Hashimoto, T. Segawa and M. Kimura: "Analysis of the Hall Effect in Micro Poly-Si Hall Devices and Origin of Offset Voltages", Electrochem. Solid-State Lett., 14, 6, pp. J26-J29 (Mar. 2011)

10)C.A. Dimitriadis, G. Kamarinos and J. Brini: "Model of Low Frequency Noise in Polycrystalline Silicon Thin-Film Transistors", IEEE Electron Device Lett., 22, 8, pp.381-383 (Aug. 2001)

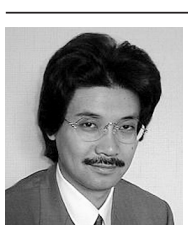

菜棕睦 1991 年, 京都大学大学院工学研究科物 理工学専攻修士課程修了. 同年, 松下電器産業 (株) 入社. 1995 年, セイコーエプソン (株) 入社. 2003 年, 龍谷大学 理工学部講師. 2005 年, 同大学助教授. 2008年, 同大学 教授. 薄膜トランジスタの電気特性解析, シミュレータ 開発, 新規応用提案などに従事. 博士 (工学).

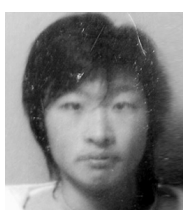

吉贺唯 朗登 2015年, 龍谷大学理工学部電子情報学 科卒業. Poly-Siホール素子の研究開発に従事.

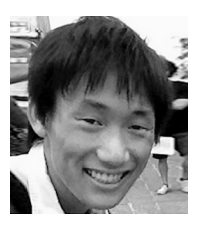

松架架賀暗 2015 年, 龍谷大学理工学部電子情報学 科卒業. IGZOホール素子の研究開発に従事.

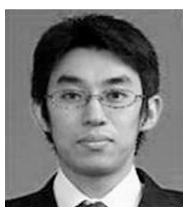

松势 時皆 2003 年, 大阪大学大学院理学研究科宇 宙地球科学専攻博士後期課程修了. 同年, 大阪大学大学 院理学研究科教務補佐員・ブラジルサンパウロ州立大学 FAPESP 博士研究員. 2004 年, 高知工科大学ナノデバイ 又研究所助教・高知県産業振興センター研究員. 2011年, 龍谷大学理工学部助教. 酸化物半導体薄膜・デバイスの 研究・評価・開発などに従事. 博士 (理学).

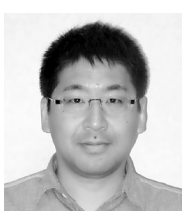

小澤 德郎 1990年, 千葉大学工学部画像応用工学 科卒業. 同年, セイコーエプソン (株) 入社. 2012 年, （株）日本エーユー・オプトロニクス入社. TFT 回路設計 およびデバイス開発に従事.

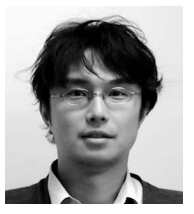

青青喜 市司 2001 年, 武蔵工業大学大学院工学研究 科電子電子工学専攻修士課程修了. 同年, (株) アルプス 技研入社. 2012 年，(株）日本エーユー・オプトロニクス 入社. 液晶ディスプレイ拉よびセンサデバイスの研究開 発に従事.

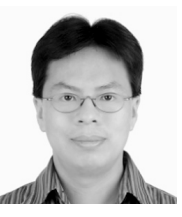

㗷志徹 2001 年, 東京大学大学院工学系研究科 精密工学専攻博士課程修了. 2002 年, TECO Nanotech 入社. 2010 年, AU Optronics入社. 2012 年, (株) 日本 エーユー・オプトロニクス転勤. 2015年, AU Optronics 復帰. 新規アプリケーションのための革新的デバイスの 開発に従事. Ph. D.. 